\title{
Molecular Identification and Next-Generation Sequence Analysis of Interspecies Genetic Variations among Three Varieties of Datura
}

\author{
Goli Penchala Prasad, Goli Penchala Pratap', Srinivasan Marimuthu, Shyam Baboo Prasad, Gajendra Rao, \\ Anupam Kumar Mangal'2, Naryanam Srikanth ${ }^{2}$
}

Regional Ayurveda Institute for Fundamental Research, Pune, Maharashtra, 'Central Research Institute of Unani Medicine, Hyderabad, Telangana, ${ }^{2}$ Central Council for Research in Ayurvedic Sciences, New Delhi, India

\begin{abstract}
Background: Datura is a well-known plant used in Ayurveda. It is a widely growing plant from Solanaceae family, attributed to poisonous and medicinal values. It is used in the treatment of various skin diseases, fever, etc., It is also used for external application and rarely for oral administration. Objectives: The present study aims to compare three different varieties of Datura which include the species of Datura innoxia Mill., Datura metel L. and Datura arborea are used to study molecular marker and phylogenetic analysis. Materials and Methods: Whole-genomic DNA was isolated from the leaves of Datura and the polymerase chain reactions amplification of DNA barcoding markers are rbcl, mat k, and internal transcribed spacer-4 and 5 were analyzed by $0.8 \%$ agarose gel electrophoresis. Results: The DNA barcoding markers and next-generation sequencing are able to identify the interspecies genetic variations among these closely related plant varieties of Datura. Conclusion: The interspecies genetic variations among these closely related three species of $D$. innoxia, metel, and arborea was closely related with Datura stramonium isolate NN003 chloroplast genome similarity of $98 \%, 99 \%$, and $99 \%$, respectively.
\end{abstract}

Key words: Ayurveda, Datura, internal transcribed spacer 4, mat k, medicinal plants, next-generation sequencing, ribulose bisphosphate carboxylase/oxygenase form I gene

\section{SUMMARY}

- Datura is a widely growing medicinal plant belonging to the family of solanaceae

- The study is designed to evaluate the molecular identification of genetic variations among these closely related three varieties of Datura to understand the molecular similarities

- We have performed molecular markers such as rbcl, mat k, internal transcribed spacer, and next-generation sequencing

- The interspecies genetic variations among these closely related three species of Datura innoxia, Datura metel, and Datura arborea were closely related with Datura stramonium.

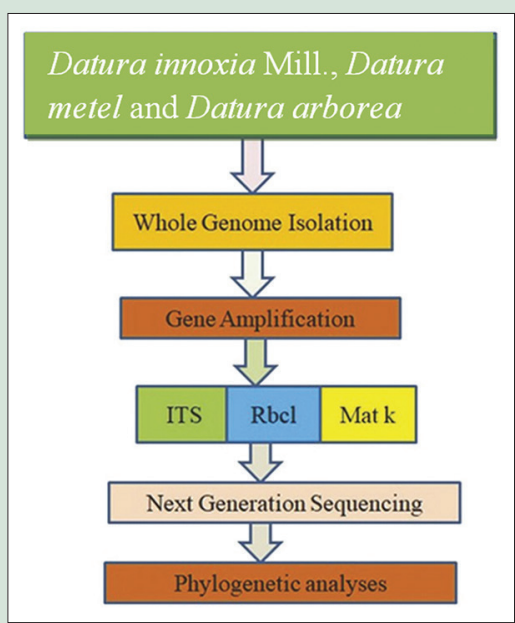

Abbreviations Used: Rbcl: Ribulose bisphosphate carboxylase/oxygenase form I gene; mat k: Maturase K; ITS: Internal transcribed spacer; PCR: Polymerase chain reactions; TAE: Tris-Acetate-EDTA buffer; BLAST: Basic Local Alignment Tool; MEGA: Molecular Evolutionary Genetics Analysis; rRNA: Ribosomal RNA.

\section{Correspondence:}

Dr. Srinivasan Marimuthu,

Biochemistry Section,

Regional Ayurveda Institute for

Fundamental Research, Kothrud,

Pune - 411 038, Maharashtra, India.

E-mail: srinimarimuthu@gmail.com

DOI: 10.4103/pr.pr_101_19

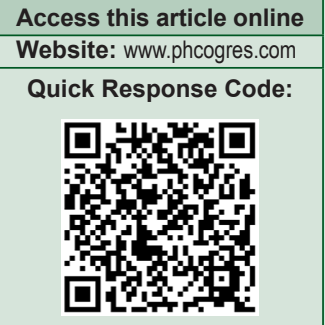

\section{INTRODUCTION}

Datura is mentioned in ancient classical literature like Charaka by the name of Kanaka. ${ }^{[1]}$ Sushruta described Datura for the treatment of dog bites. Bhavamishra described Datura leaf externally for the treatment of lice, for analgesic and anti-inflammatory actions. ${ }^{[2]}$ Vangasena described Datura seeds are used after purification processes by boiling in cow milk and shade dried in the room temperature and used it for filariasis. ${ }^{[3]}$ Datura is known by the name thorn apple is a poisonous herb. It is used in many Ayurvedic medicines after the purification method. ${ }^{[4]}$ Leaves of Datura are used in alopecia, pain in the breast, tumor, rheumatism, and in inflammation and its flowers are anti-asthmatic. The leaves, seeds, and roots are anti-catarrhal and used in bronchial asthma, skin diseases, wounds, cough, burning micturition, mental illness, febrifuge, diarrhea, and dermatosis. Its chemical composition scopolamine, daturadiol, hyoscyamine, fastudine, allantoin, niacin, Vitamin C, atropine, noratropine, meteolodine, hyoscine, fastusic acid, etc. ${ }^{[5]}$

Among all its varieties, Krishna Datura (black) is attributed to prime potentialities. In Rajanighantu, five varieties of Datura have been

This is an open access journal, and articles are distributed under the terms of the Creative Commons Attribution-NonCommercial-ShareAlike 4.0 License, which allows others to remix, tweak, and build upon the work non-commercially, as long as appropriate credit is given and the new creations are licensed under the identical terms.

For reprints contact: reprints@medknow.com

Cite this article as: Prasad GP, Pratap GP, Marimuthu S, Prasad SB, Rao G, Mangal AK, et al. Molecular identification and next-generation sequence analysis of interspecies genetic variations among three varieties of Datura. Phcog Res 2020;12:158-62. 
mentioned based on the flowering color of the plant (white, blue, black, red, and yellow). ${ }^{[6]}$ In this study, three varieties of Datura which include the species of D. innoxia, D. Metel and Datura arborea were studied. The aim of the present study is to evaluate the molecular identification of $\mathrm{rbcl}$, mat $\mathrm{k}$, and internal transcribed spacer (ITS) 4 and 5 universal genes and next-generation sequencing (NGS) are used to explore the interspecies genetic variation among these closely related three plant varieties.

\section{MATERIALS AND METHODS}

\section{Chemicals}

Plant DNA isolation kit was purchased from Favorogen, polymerase chain reactions (PCR) master mix (2X) from Genetix Biotech Asia Pvt. Ltd., New Delhi, India. Agarose, 6X gel loading dye and 100 bp and $1 \mathrm{~Kb}$ DNA ladder were procured from Himedia Laboratories PVT, LTD, Mumbai, India, Primers mat k, rbcl, and ITS-4 and 5 was synthesized by Eurofins Genomics India Pvt. Ltd, Bangalore, Karnataka, India. All other chemicals and solvents were of analytical grade and obtained from Himedia, Mumbai, India.

\section{Plant collection}

Fresh leaves of Datura are D. Innoxia, D. metel and D. arborea were collected from the Medicinal plant garden at Regional Ayurveda Institute for Fundamental Research (RAIFR), Kothrud, Pune, Maharashtra, India [Figure 1]. The plant specimen was authenticated by Dr. Gajendra Rao, Research officer an expert in the field of Botany and live plants are being maintained in the Arborium/Garden of in

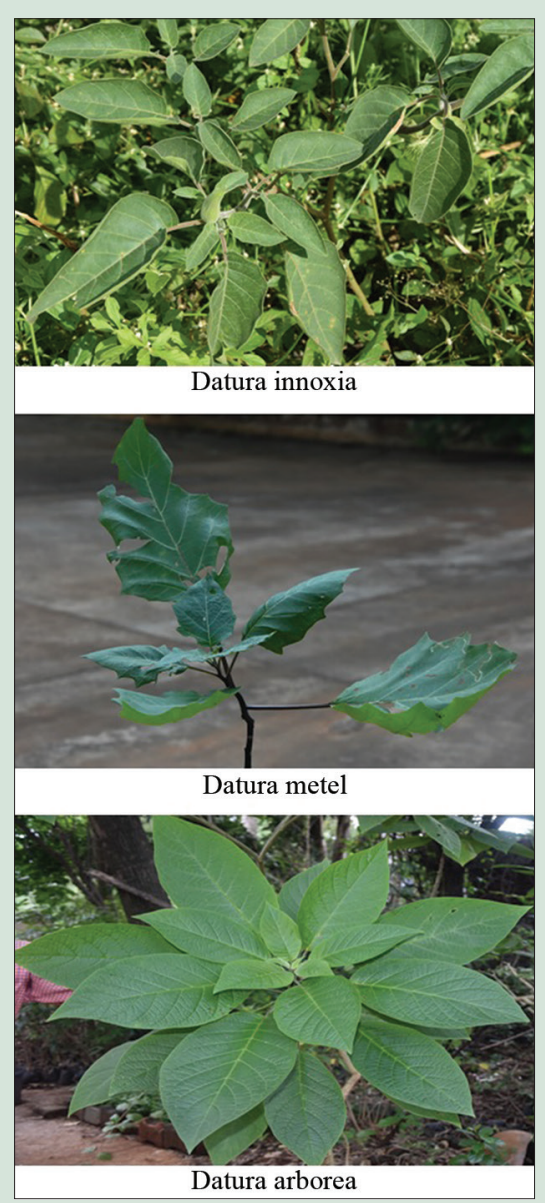

Figure 1: Photography images of three varieties of Datura species
RAIFR, Pune, Maharashtra, India, with a registration number of DMA-01, DMI-02, and DMD-03.

\section{Extraction of whole-genomic DNA}

The leaves of Datura varieties D. Innoxia Mill., D. metel and D. arborea $100 \mathrm{mg}$ of each leaf were crushed with liquid nitrogen into a fine powder. Total genomic DNA was extracted from all the samples using the Favorgen Plant genomic DNA extraction kit. A Nanodrop was used to determine the concentration of genomic DNA. The integrity of DNA was confirmed by visualization on $0.8 \%$ agarose gel using ethidium bromide staining.

\section{Polymerase chain reactions amplification}

The extracted DNA was used as a DNA template in the PCR reaction. PCR amplification was conducted in $25 \mu \mathrm{l}$ of PCR mixture containing $12.5 \mu \mathrm{l}$ of PCR master mix (2X), $10 \mu \mathrm{M}$ forward and reverse primer ( $2 \mu \mathrm{l}$ each), $3.5 \mu \mathrm{l}$ nuclease-free water, and $10 \mathrm{ng}$ of template DNA. The thermal cycling conditions were initial denaturation at $94^{\circ} \mathrm{C}$ for $5 \mathrm{~min}, 35$ cycles of denaturation at $94^{\circ} \mathrm{C}$ for 30 -s annealing at $50^{\circ} \mathrm{C}$ for $1 \mathrm{~min}$, extension at $72^{\circ} \mathrm{C}$ for $2 \mathrm{~min}$ followed by a final extension at $72^{\circ} \mathrm{C}$ for $10 \mathrm{~min}$. The amplified products were detected by $0.8 \%$ agarose gel electrophoresis in Tris-Acetate-EDTA (TAE) buffer and visualized with ethidium bromide staining. Primers used for amplification of ITS-5 and 4, mat k, and rbcl genomic regions shown in Table 1.

\section{Amplification and next-generation sequence analysis}

PCR was performed using the rbcl gene region. The reaction mixture was done in $25 \mu \mathrm{L}$ consisting of the $12.5 \mu \mathrm{l}$ of PCR master mix (2X), $0.25 \mu \mathrm{M}$ forward and reverse primer, and $3.5 \mu \mathrm{l}$ nuclease-free water and $10 \mathrm{ng}$ of template DNA. The reaction mixture was incubated at $94^{\circ} \mathrm{C}$ for $1 \mathrm{~min}$ and amplification was performed with the following 35 thermal cycles; denaturation for the $30 \mathrm{~s}$ at $94^{\circ} \mathrm{C}$, annealing for $40 \mathrm{~s}$ at $53^{\circ} \mathrm{C}$, an extension for $40 \mathrm{~s}$ at $72^{\circ} \mathrm{C}$, and the final extension for $5 \mathrm{~min}$ at $72^{\circ} \mathrm{C}$. The amplified PCR products were detected by $0.8 \%$ agarose gel electrophoresis in TAE buffer and visualized with ethidium bromide staining. Sequenced products were precipitated using two volumes of $80 \%$ propanol and then washed twice with $80 \%$ ethanol. The PCR-products were air-dried and resuspended in a denaturing buffer containing $15 \mu \mathrm{L}$ of formamide. The final sequencing was done using Applied Biosystems DNA sequencer following standard protocol. Sequence analyzing was outsourced to Eurofins Genomics India Pvt. Ltd, Bangalore, Karnataka, India and was analyzed by NGS. The nucleotide sequence for rbcl gene sequence was subjected to sequence alignment using the Basic Local Alignment Tool (BLAST). The number of hits with homologous sequences is inferred based on similarity and alignment.

\section{Phylogenetic tree}

Molecular Evolutionary Genetics Analysis version 10, was used to construct a maximum likely hood tree for the obtained sequences to identify its interspecies relationships.

Table 1: Primers used for amplification of ITS-5 and 4, mat k, and rbcl genomic regions

\begin{tabular}{ll}
\hline Primer name & Sequences $\left(5^{\prime}-3^{\prime}\right)$ \\
\hline ITS5-forward & 5'-GGAAGTAAAAGTCGTAACAAGG-3' \\
ITS4-reverse & 5'-TCCTCCGCTTATTGATATGC-3' \\
mat k-forward & 5'-TAATTTACGATCAATTCATTC-3' \\
mat k-reverse & 5'-CTTCCTCTGTAAAGAATTC-3' \\
rbcl-forward & 5'-ATGTCACCACAAACAGAGACTAAAGC-3' \\
rbcl-reverse & 5'-GTAAAATCAAGTCCACCRCG-3' \\
\hline
\end{tabular}

ITS: Internal transcribed spacer; mat k: Maturase K; rbcl: Ribulose bisphosphate carboxylase/oxygenase form I gene 


\section{RESULTS}

\section{Genomic DNA quantification}

The extracted plant DNA was analyzed using Nanodrop Eppendorf. The obtained DNA concentration from the $D$. innoxia was $20 \mathrm{ng} / \mu \mathrm{l}, D$. metel was $25 \mathrm{ng} / \mu \mathrm{l}$ and $D$. arborea was $22 \mathrm{ng} / \mu \mathrm{l}$, respectively. Hence, due to the good quality of genomic DNA concentrations in all three varieties of Datura was used as a DNA template for rbcl, mat k, and ITS- 4 and 5 for further molecular marker analyses.

\section{Internal transcribed spacer 4 and 5 gene amplification}

ITS is the spacer DNA situated between the small subunit ribosomal RNA (rRNA) and large subunit rRNA genes in the chromosomes. Figure 2 shows the changes in the ITS- 4 and 5 universal gene amplification to generate the PCR product approximately 670 base pairs (bp) in size of agarose gel electrophoresis. The gene was amplified successfully in D. innoxia, D. metel and D. arborea.

\section{Rbcl and Mat $\mathrm{k}$ gene amplification}

Figures 3 and 4 show the changes in the rbcl and mat kene amplification to generate the PCR product of agarose gel electrophoresis. The results of DNA barcode performances with mat $\mathrm{k}$ and $\mathrm{rbcl}$ regions in the three varieties of Datura. The amplification of the gene was successful only in the rbcl gene region, The fragment sizes are about $550 \mathrm{bp}$. Mat $\mathrm{k}$ gene expression was less amplified when compared with $\mathrm{rbcl}$ gene. All the varieties of Datura, rbcl gene amplification are similar when compared with mat k gene.

\section{Next-generation sequence analysis}

Table 2 shows the statistical simulation of BLAST sequence homology of $D$. innoxia, D. metel and $D$. arborea species with rbcl primers, respectively. Sequence homology of the amplified sequence was detected using BLAST. The sequence length of rbcl was 614, 611 and 610 nucleotides with $D$. innoxia, metel and arborea varieties, respectively. Similarily with rbcl sequence homology of all the three species was $98 \%, 99 \%$, and $98 \%$, respectively.

Table 3 shows the identification of single gene mutation of three varieties of $D$. innoxia, metel and arborea varieties with rbcl primers, respectively. We observed that species-specific substitution as marker

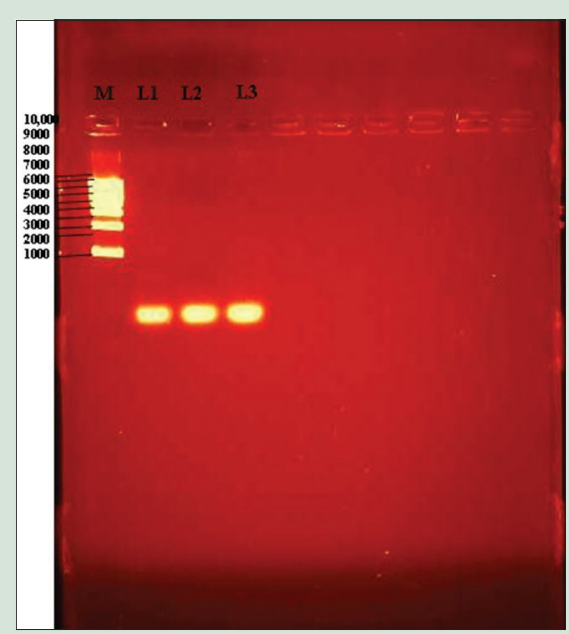

Figure 2: M represents marker $1 \mathrm{~kb}$ DNA ladder and Lanes $L 1$ - D. innoxia of internal transcribed spacer, L2 - D. metel of internal transcribed spacer and L3 - D. arborea of internal transcribed spacer nucleotides because they may be crucial for identifying each species. In $D$. innoxia, there is a mismatch sequence which was observed at the position of $125,129,444,459,592$, and 605 and insertion was observed at the position of 130-132 and 30134. In D. metel species the mismatch sequences were observed at the position of 437 and 607 nucleotide sequences and the insertion was observed at the position of 111 , 25481, 58541-58542. In $D$. arborea species we found that mismatch sequences were observed at the position of $10,12,46,437,605$, and 606 , respectively, and the insertion was observed at the sequence of $141,597-599$.

\section{Phylogenetic analysis}

To evaluate the phylogenetic relationships among the three varieties of D. innoxia, metel and arborea, phylogenetic trees were constructed by applying the $\mathrm{NJ}$ method to the rbcl sequences. As shown in the result of the phylogenetic tree [Figure 5], when all the three DNA barcodes sequences were employed, Datura metel and D. innoxia were closer genetically similar when compared to $D$. arborea. Therefore, the rbcl barcode sequences provided higher resolution for the identification of the clusters that constitute clades within the same species. From these phylogenetic analyses, we confirm that the identification of the three varieties can be achieved using rbcl universal gene.

\section{DISCUSSION}

DNA barcoding is a popular method for species identification of fresh tender leaves. It is mainly used to verify plants that lack flowers or have incomplete morphological characteristics. It is also to be used in samples such as processed food, fossil remains and herbarium specimens, in which the DNA has been highly degraded. ${ }^{[7]}$ It involves sequencing a standard region of DNA as a tool for species identification. ${ }^{[8]} \mathrm{Rbcl}$, mat k, and ITS- 4 and 5 possess attributes that are highly desirable in a plant DNA barcoding system, although none of the three loci fits all three criteria perfectly. Chase, in 2007, reported that using two barcoding region $\mathrm{rbcl}$ and mat $\mathrm{k}$ options as a standard protocol for barcoding of all land plants. ${ }^{[9]}$ Consortium for the barcode of life's plant working group reported that DNA barcodes with mat $\mathrm{k}$ and $\mathrm{rbcl}$ gene loci are the use of two regions of plastid DNA as a standard protocol for the core barcoding of land plants. ${ }^{[10]}$ In this study, we assessed the molecular markers of ITS- 4 and 5, mat $\mathrm{K}$, and $\mathrm{rbcL}$ and next-generation sequences are used to identify the interspecies genetic variations among these closely related three species of Datura.

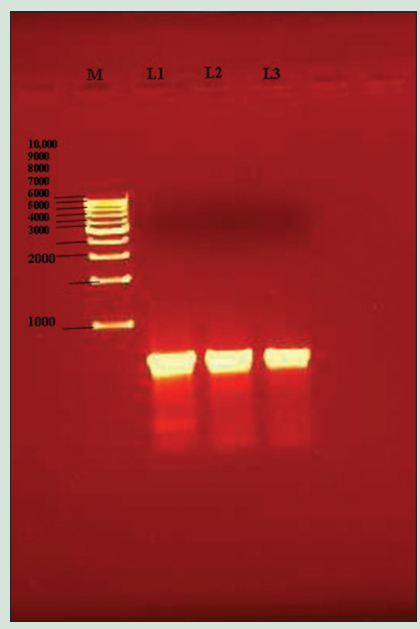

Figure 3: $M$ represents marker $1 \mathrm{~kb}$ DNA ladder and Lanes L1 - D. innoxia of rbcl gene, L2 - D. metel of rbcl gene, L3 - D. arborea of rbcl gene 
Table 2: Statistical simulation of Basic Local Alignment Tool sequence homology of $D$. innoxia, D. metel and $D$. arborea varieties with rbcl primers, respectively

\begin{tabular}{|c|c|c|c|c|c|c|}
\hline Species & Scientific name & Reference ID & Best hit & Gene & Max score & Query cover (\%) \\
\hline \multirow[t]{2}{*}{ Datura } & D. innoxia & JN662489.1 & Datura stramonium & RBCL & 990 & 95 \\
\hline & & МН311563.1 & Datura metel & $\mathrm{RBCL}$ & 966 & 95 \\
\hline \multirow[t]{2}{*}{ Datura } & D. metel & JN662489.1 & Datura stramonium & $\mathrm{RBCL}$ & 996 & 99 \\
\hline & & KF365991.1 & Datura innoxia & $\mathrm{RBCL}$ & 981 & 97 \\
\hline \multirow[t]{2}{*}{ Datura } & D. arborea & JN662489.1 & Datura stramonium & RBCL & 990 & 98 \\
\hline & & МН311563.1 & Datura metel & RBCL & 966 & 94 \\
\hline
\end{tabular}

RBCL: Ribulose bisphosphate carboxylase/oxygenase form I gene

Table 3: Identification of single gene mutation of three varieties of $D$. innoxia, D. metel, and D. arborea

\begin{tabular}{llcc}
\hline Species & Scientific name & Mismatch & Insertion \\
\hline Datura & D. innoxia & $125(\mathrm{G}, \mathrm{T}) ; 129(\mathrm{C}, \mathrm{G}) ; 444(\mathrm{~A}, \mathrm{G}) ; 459(\mathrm{~A}, \mathrm{G}) ; 592$ & $130-132(\mathrm{TGA},---) ; 30134(\mathrm{~A},-)$ \\
& & $(\mathrm{C}, \mathrm{G}) ; 605(\mathrm{~A}, \mathrm{~T})$ & \\
Datura & D. metel & $437(\mathrm{~A}, \mathrm{G}) ; 607(\mathrm{~A}, \mathrm{C})$ & $111(\mathrm{C},-) ; 25481(\mathrm{C},-) ; 58541-58542(\mathrm{AT},--)$ \\
Datura & D. arborea & $10(\mathrm{~A}, \mathrm{C}) ; 12(\mathrm{C}, \mathrm{A}) ; 46(\mathrm{G}, \mathrm{A}) ; 437(\mathrm{~A}, \mathrm{G}) ; 605-606(\mathrm{TA}, \mathrm{AC})$ & $141(\mathrm{C},-) ; 597-599(\mathrm{GAA},---)$ \\
\hline
\end{tabular}

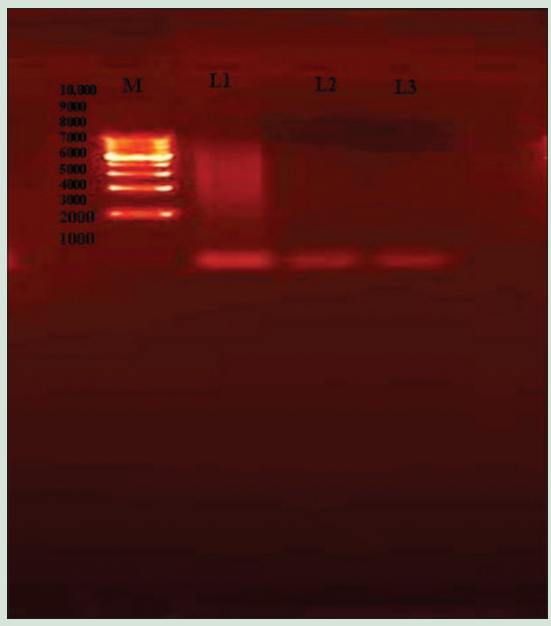

Figure 4: $M$ represents marker $1 \mathrm{~kb}$ DNA ladder and Lanes $L 1$ - D. innoxia of mat k gene, L2 - D. metel of mat k gene, L3 - D. arborea of mat k gene

The results of PCR amplification revealed that the two molecular markers ITS- 4 and 5 and $\mathrm{rbcl}$ genes are amplified successfully, but in the case of mat $\mathrm{k}$ gene was not amplified when compared with the other two genes. The inter and intraspecific distances of ITS were greater than those of mat $\mathrm{k}$ and $\mathrm{rbcl}$. Various studies have shown that the interspecific sequence divergence among DNA barcode regions is the highest in ITS followed by mat $\mathrm{k}$ and $\mathrm{rbcl}$ region. DNA barcode regions in plant systems can be divided into protein-coding and noncoding regions. Noncoding regions such as the nuclear ribosomal ITS, whereas protein-coding regions such as mat $\mathrm{k}$ and $\mathrm{rbcl} .^{[11]}$

NGS is another facility of advanced genomics era to have a more precise picture of species genome and to identify more orthologous and paralogous regions at different loci of different species. ${ }^{[12]}$ The sequencing of the entire plastid genome along with ITS is becoming a method of choice for species discrimination. In the present study, we amplified rbcl gene region and sequenced the conserved regions in three varieties of D. innoxia, metel and arborea. Sequence homology of the amplified sequences was detected using BLAST. ${ }^{[13]}$ In the present study, we have identified the rbcl gene sequence homology of all the three varieties of D. innoxia, metel and arborea. D. arborea was $98 \%$ related to Datura stramonium and $94 \%$ related to Datura metel. D. innoxia $95 \%$ related to D. stramonium and $95 \%$ related to Datura metel. Datura metel closely related to D. stramonium $99 \%$ and D. innoxia $97 \%$, respectively.

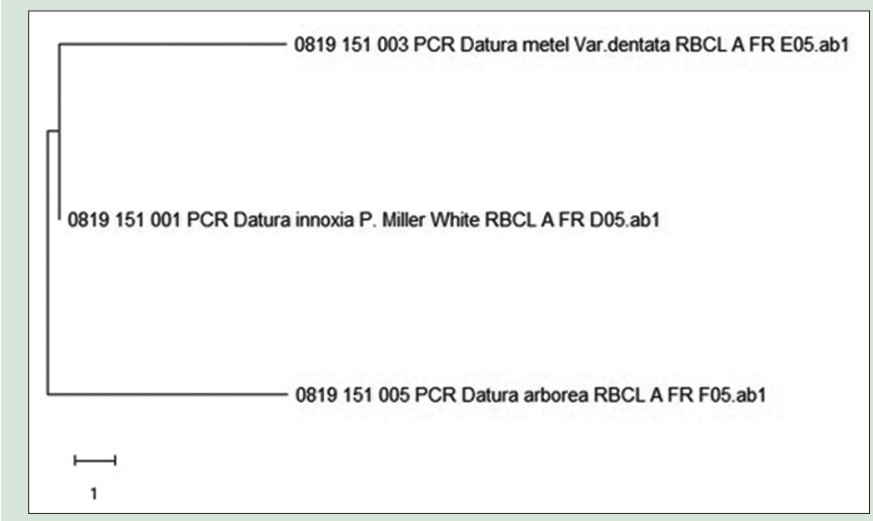

Figure 5: Phylogenetic tree showing common linkeage between D. innoxia, D. metel and D. arborea

\section{CONCLUSION}

Thus, from the results obtained, we observed that the molecular markers of ITS-4 and 5, mat k, and rbcl gene amplification and sequencing are used to identify the interspecies genetic variations among these closely related three varieties of $D$. innoxia, D. metel, and $D$. arborea was closely related with $D$. stramonium isolate NN003 chloroplast genome similarity of $98 \%, 99 \%$, and $99 \%$, respectively. Datura metel and innoxia were closer genetically similar when compared to $D$. arborea variety. Rbcl barcode sequences provided higher resolution for the identification of the clusters that constitute clades within the same species. Phylogenetic analyses confirm that the identification of the three varieties of Datura metel can be achieved using rbcl universal gene sequence analysis.

\section{Acknowledgements}

The authors express their sincere thanks to the Central Council for Research in Ayurvedic Sciences, New Delhi, India, for providing financial assistance and all necessary facilities.

\section{Financial support and sponsorship}

CCRAS, New Delhi, India.

\section{Conflicts of interest}

There are no conflicts of interest. 


\section{REFERENCES}

1. Lucas DS. Oriental publisher and distributors. In: Chaukhambha Visvabharati. Vol. 2. Varanasi, India: Oriental Publisher and Distributors; 2013. p. 1-911.

2. Sastry JL. Illustrated Dravyaguna: Vijnana Study of the Essential Medicinal Plants in Ayurveda. Varanasi: India: Chaukambha Orientalia; 2014. p. 1-1047.

3. Nishteswar K, Hemadri K. Dravyaguna Vijnana: Chaukhambha Sanskrit Pratishthan. Delhi: India: Chaukhambha Sanskrit Pratishthan; 2013. p. 1-493.

4. Monira KM, Munan SM. Review on Datura metel: A potential plant. Global J Res Med Plants Indig Med 2012;4:123-32.

5. Thomas S, Parihar BK, Sharma G, Kadibagil VR. Critical appraisal of dhattura (Datura metel Linn.) in ayurvedic formulations. J Ayurveda Holist Med 2016;4:32-46.

6. Kadam SD, Chavhan SA, Shinde SA, Sapkal PN. Pharmacognostic review on Datura. Int J Pharmacogn Chin Med 2018;2:1-9.

7. Parveen A, Vijula K, Avinash KV, Ravishankar M, Leeladhar DV. Medicinal values of Datura: A synoptic review. Int J Green Pharm 2016;10:77-81.

8. Bansal S, Thakur S, Mangal M, Mangal AK, Gupta RK. DNA barcoding for specific and sensitive detection of Cuminum cyminum adulteration in Bunium persicum. Phytomedicine 2018;50:178-83.

9. Chase MW. A proposal for a standardized protocol to barcode all land plants. Taxon 2007;56:295-9.

10. Hollings Worth PM, Forrest LL, Spouge J. A DNA barcode for land plants. PNAS 2009;106:12794-7.

11. Hollingsworth PM, Graham SW, Little DP. Choosing and using a plant DNA barcode. PLoS One 2011;6:e19254.

12. Kim WJ, Ji Y, Choi G, Kang YM, Yang S, Moon BC. Molecular identification and phylogenetic analysis of important medicinal plant species in genus Paeonia based on rDNA-ITS, matK, and rbcL DNA barcode sequences. Genet Mol Res 2016;55:1-10

13. Watto JI, Saleem MZ, Shahzad MS, Arif A, Hameed A, Saleem MA. DNA Barcoding: Amplification and sequence analysis of $\mathrm{rbcl}$ and matk genome regions in three divergent plant species. Adv Life Sci 2016:4:3-7. 